$$
\begin{aligned}
& \text { التعويض عن الضرر البيئى } \\
& \text { ايناس مرسى محمد السنطاوى' ,عادل عبد الهادي عبد الله } \\
& \text { 'باحث دكتور راه ـ معهد الدراسات و البحوث البيئة ـ جامعة مدينة السادات }
\end{aligned}
$$

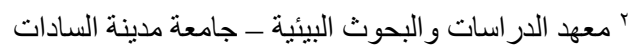

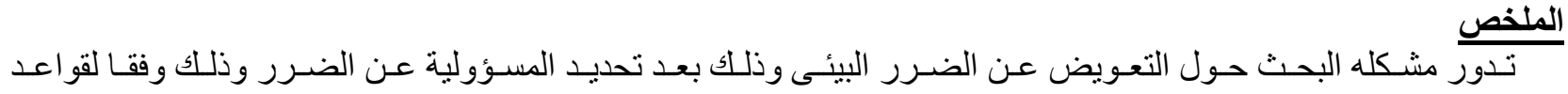

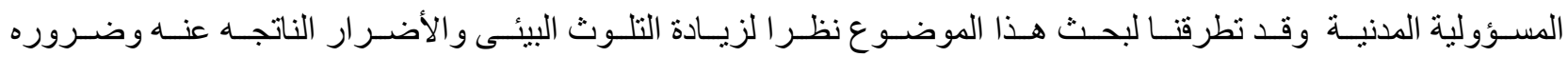

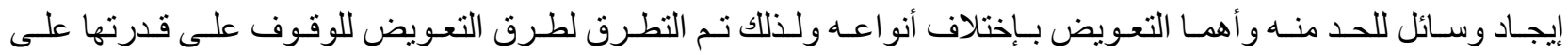

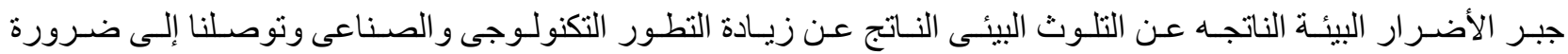

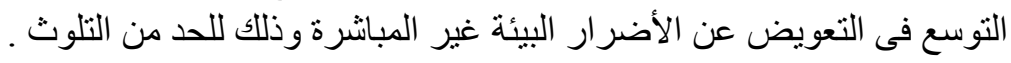

$$
\text { كلمات داله: التلوثـ البيئة_ التكنولوجى- الصناعى. }
$$

\title{
Abstract:
}

The problem of research on compensation for environmental damage is determined after determining the responsibility for the damage according to the rules of civil liability. We discussed this subject in view of the increase in environmental pollution and the damage resulting from it. It is necessary to find ways to reduce it and compensate for the different types. Environmental damage resulting from the environmental pollution resulting from the increased technological and industrial development and we have reached the need to expand compensation for indirect environmental damage to reduce pollution. .

Key worde:environmental- pollution- technological-industrial.

\section{مقدمه الاراسة}

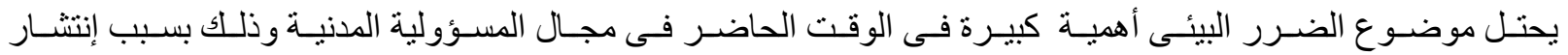

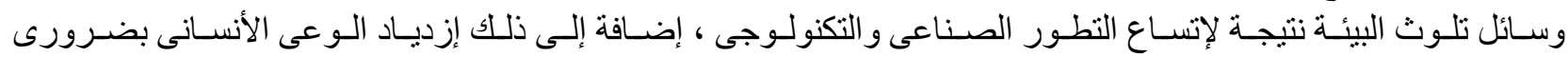

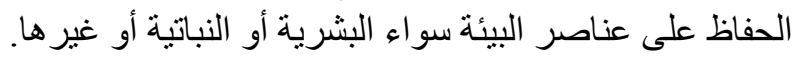

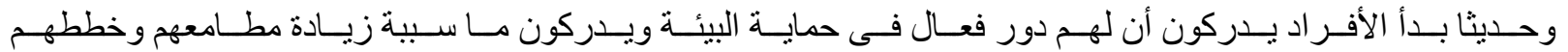

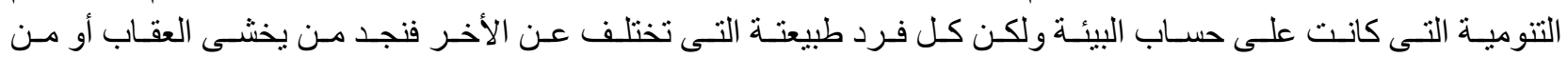

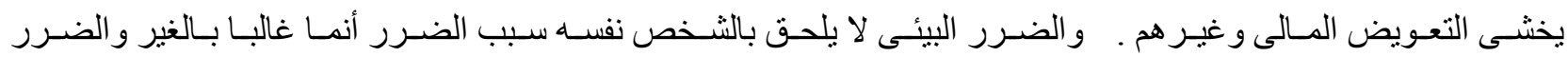

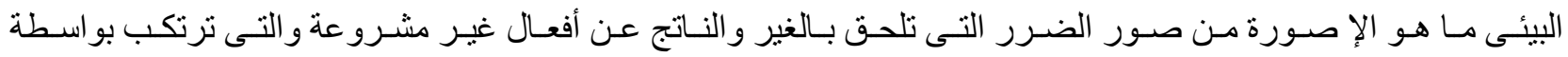

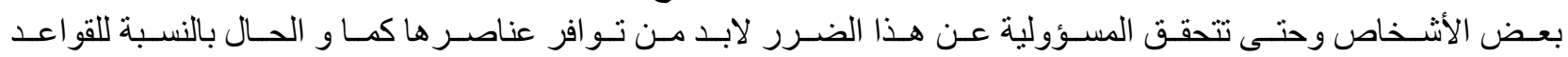

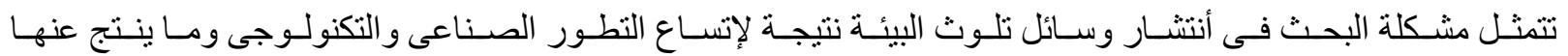

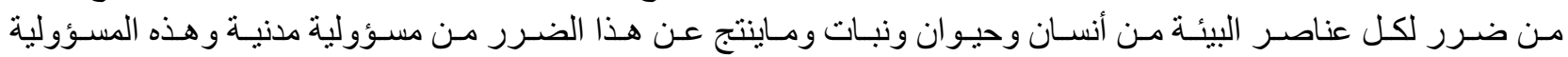

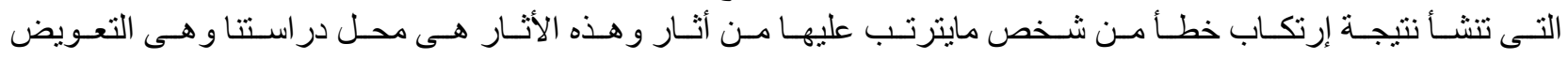
بأنو اعة و هل يؤدى هذا التعويض دورة فى الحد من الضرر البيئى وأثارة. 
فروض البحث:

هناك علاقة ذات دلالة إحصائية بين التعويض عن الضرر ومعدلات الضرر البيئى.

أهمية الدراسة:

ـالتعرف على الضرر البيئى وأنو اعة.

ـالتعرف على شروط الضرر البيئى المستوجب للتعويض .

- تحديد مفهوم التعويض وطرق التعويض .

ـ هل الطرق المتبعة فى التعويض تقوم بدور ها فى جبر الضرر البيئى .

منهج الدراسةة:

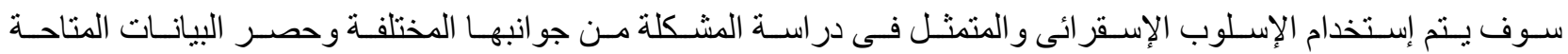
عنها لإستنباط حقيقة المشكلة محل الدر اسة الإسلة

وسوف نقوم بلراسة موضوع البحث فى أربعه مباحث على النحو التالى:

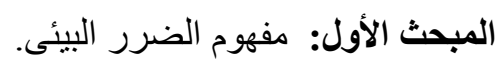

المبحث الثانى : أنواع الضرر البيئى .

المبحث الثالث: شروط الضرر البيئى المستوجب للتعويض.

المبحث الرابع : تعريف التعويض وطرق التعويض.

المبحث الأول

الضرر البيئى

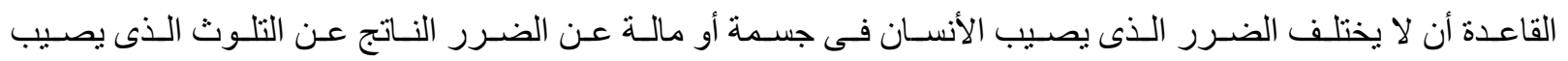

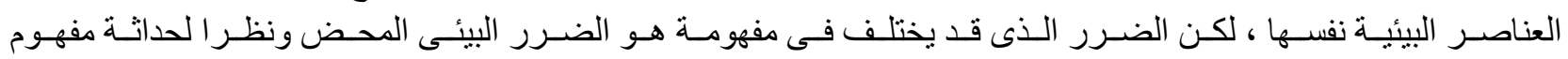

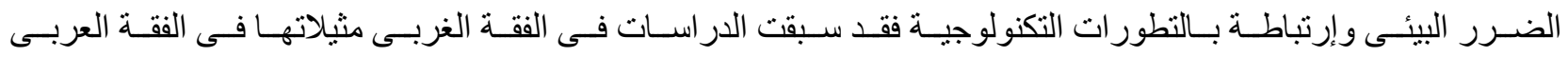

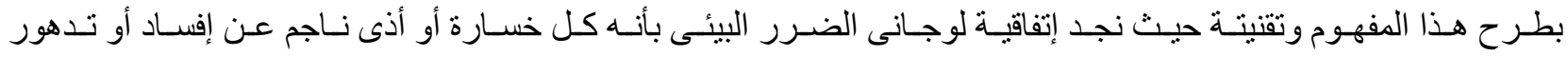
البيئة'.

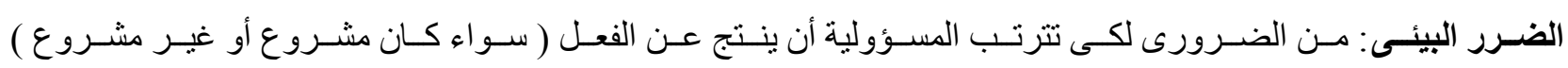
ضرر يصيب الغير و هنا يمكن القول بأن هناك ضرن البرد. ويقصد بالضرر المساس بحق أو مصلحة مشروعة لأحد أثخاص القانون الدولى'ء. ، ويمكن تعريفة أنه الخسارة المادية أو المعنوية أو الأذى الأدبى الذى يلحق به.

' د حسن فنتوش رشيد الحسناوى،" الضرر المتغير وتعويضة فى المسؤولية التقصرية" ، در اسة مقارنة ، رسسالة دكتور اة،

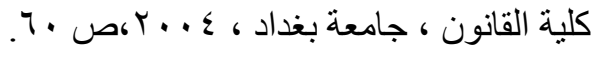

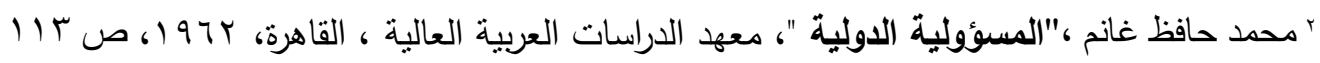




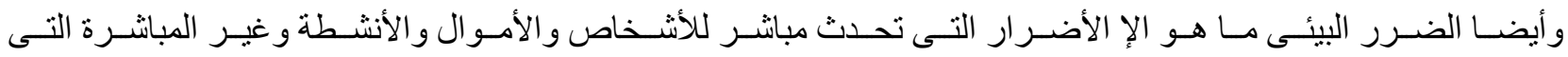

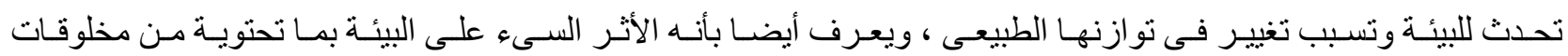

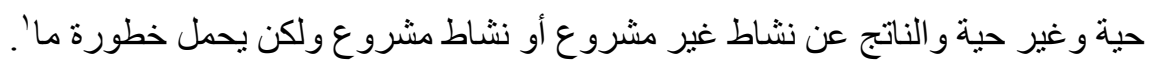

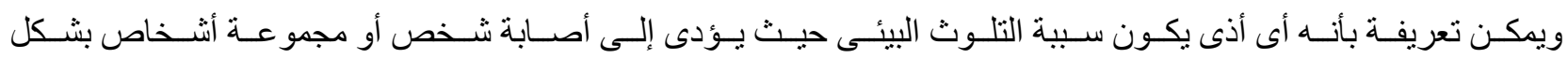

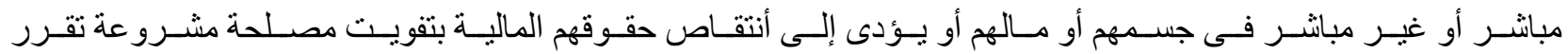

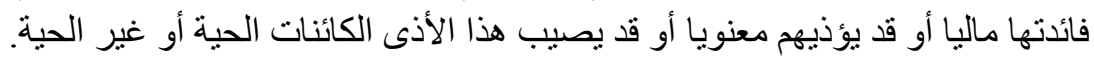

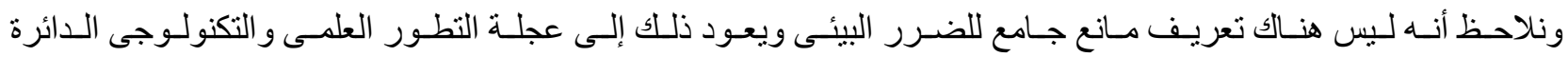

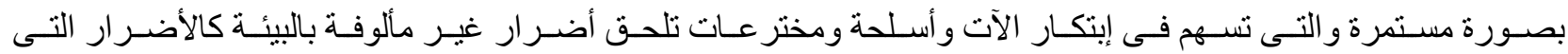

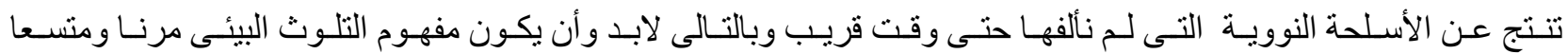
ليشمل كافة مخرجات هذا التطور الذى شهده العالم .

المبحث الثانىى

أنواع الضرر

نجد أن الضرر وفقا لمفهومة السابق ينقسم إلى:

• أولا: الضرر من حيث درجته:

أــالضرر البسيط : هو الضرر الذى يكون من الأمور المألوفة ، وتأثيرة على البيئة محددا سواء داخل الدولة أو خارجها. حيث أنه لا يتعدى حدود الدولة ، مثل عمليات شحن النفط الخام فى الناقلات و التنى غالبا مايترتب عليها تسريب نفط بسيط يؤدى إلى حدوث تلوث.

ب_الضرر الجسيم : وذلك يتعدى حدود الدولة ن وهذا الضرر عظيم التأثير والضرر الجسيم يعد من أخطر أنواع الأضرار

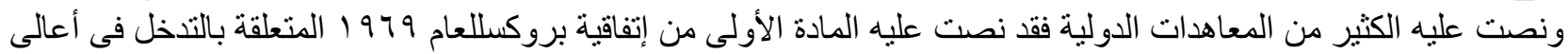

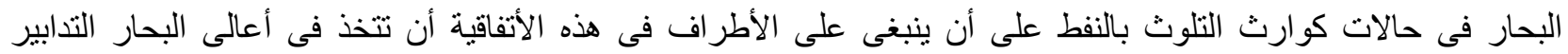

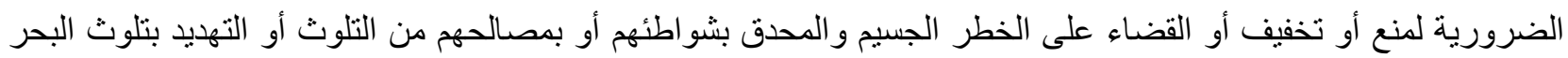

بالبترورلr

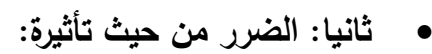

تتقم الأضر ار من حيث تأثثر ها على المضرور إلى أضرار (مادية ، ومعنوية )أو (أضرار مباشرة وغير مباشرة). أـ الضرر المادى: هو الضرر الذى يصيب المضرور فى جسمة أو مالةج .

، ويمكن تعريفة أيضا أنه كل ما يصيب الأنسان فى جسمة أو مالة أو مصلحة مالية مشرو عة؛؛

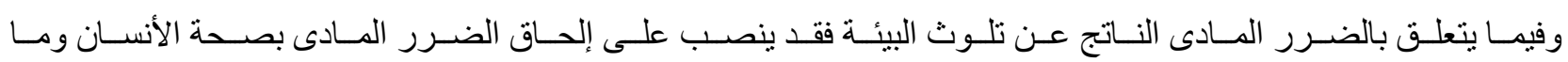

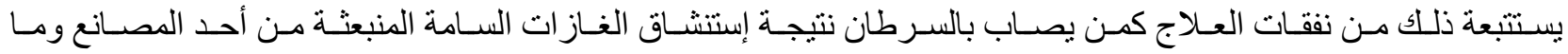

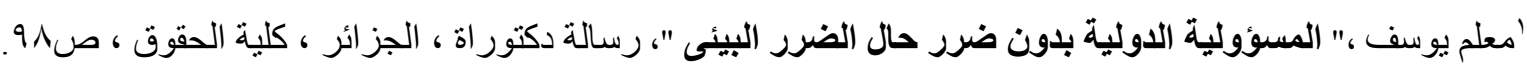

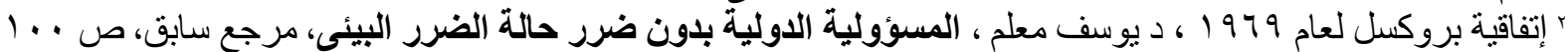

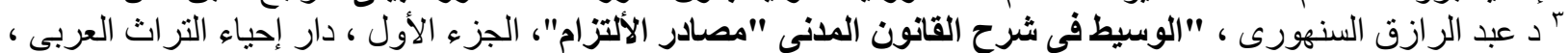

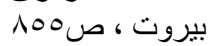

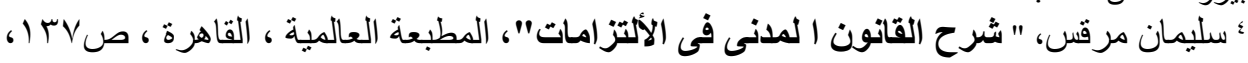




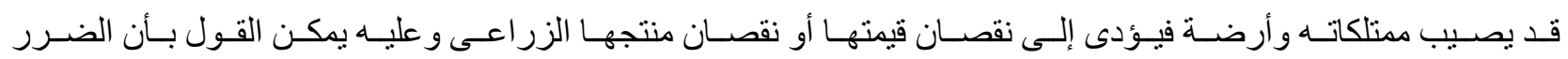

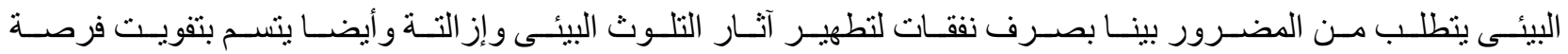

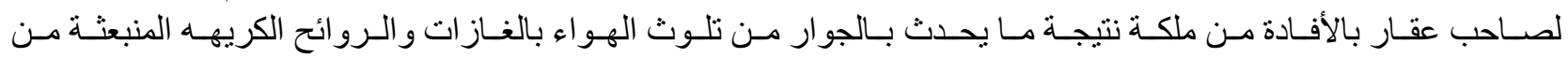
مصنع خاص بالنشادر و الكيماويات مما يؤدى إلى نقص القئ القيمة الأقتصادية للعقار .

\section{ب الضرر المعنوى (الأدبى):}

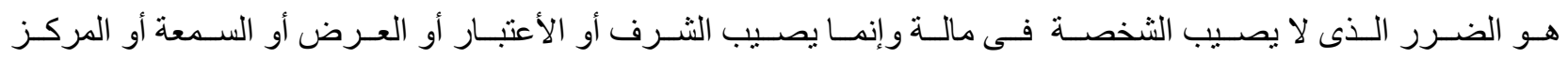

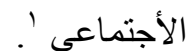

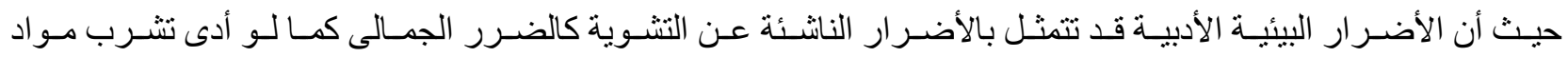

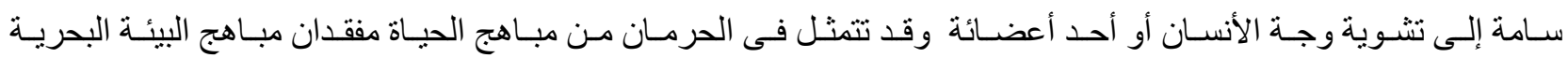

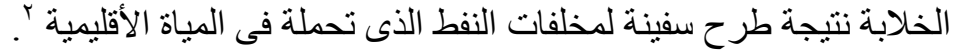

جـ الضرر المباثر : هو ما لحق الأنسان من خسارة وما فاته من كسب حيث يقع على المصالح أو الأموال؟ّ. دـ الضرر غير المباشر: فهو كل خسارة و اقعة على العناصر الطبيعية المكونه للبيئة نفسها؛.

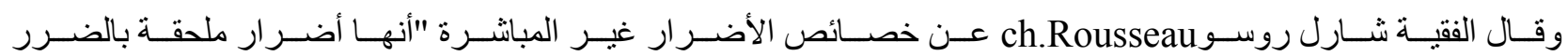

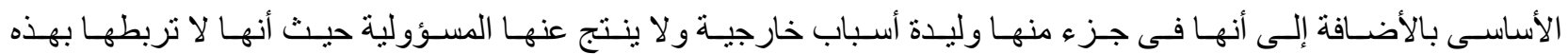
المسؤولية سوى علاقة بعيدة.

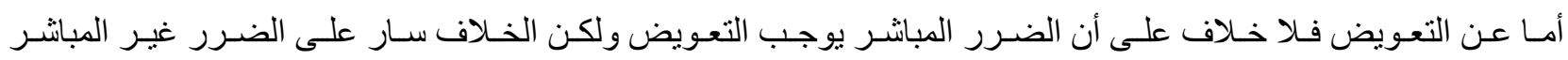

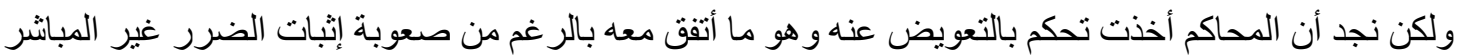

خاصة بالنسبة للأضر ار البيئية الإ أنه يجب تعويضها.

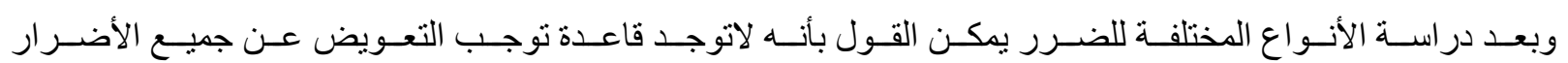

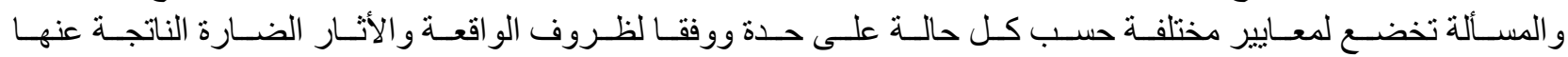
وتأثنير ها على الأنسان و البيئة و المحيط.

المبحث الثالث

شروط الضرر البيئى المستوجب للتعويض

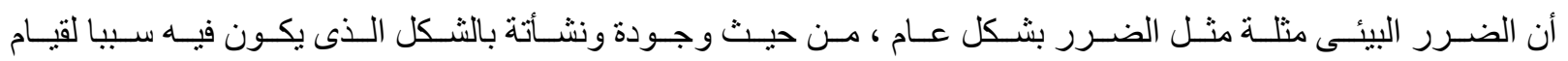

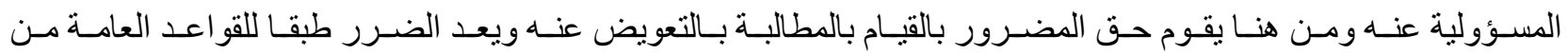

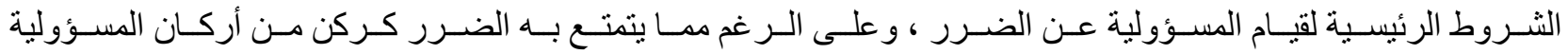

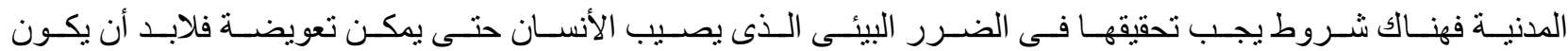

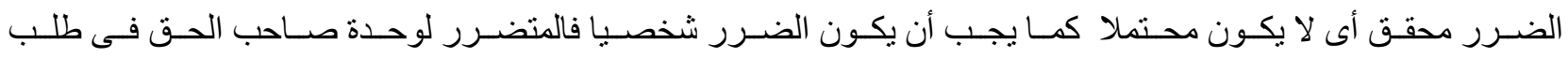

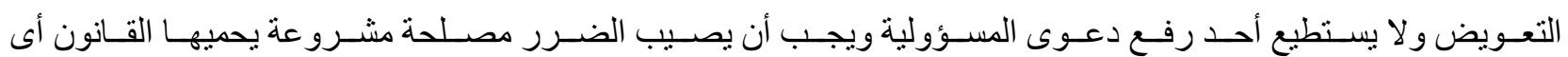

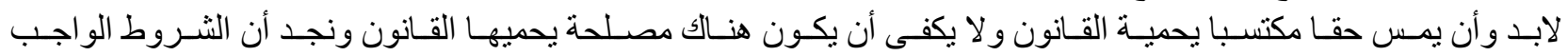

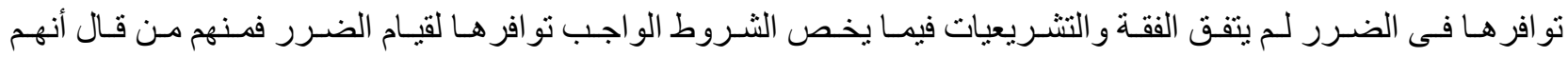
' ابر اهيم صالح الصرايرة،"مدى كفاية القواعد العامة فى التعويض عن الضرر البيئى فى القانون المدنى الأردنى "، جامعة

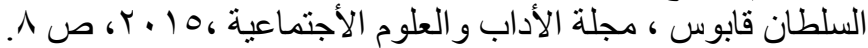

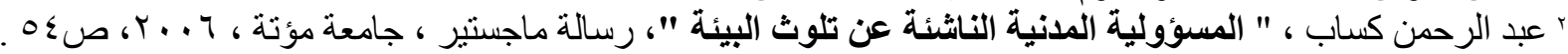

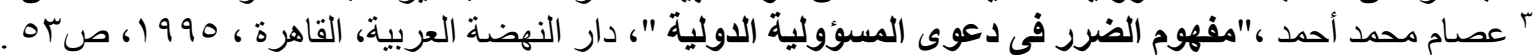

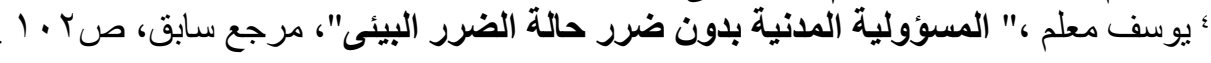




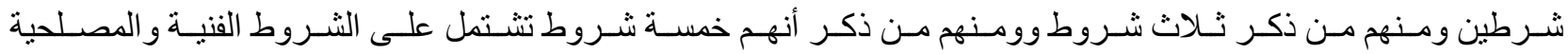

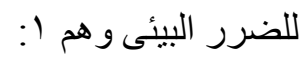
أن يكون الضرر البيئي محققا:

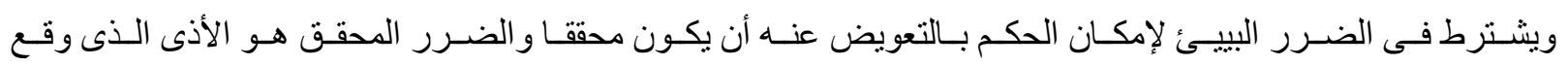
فى الحال أو سيقع فى المستقبل .

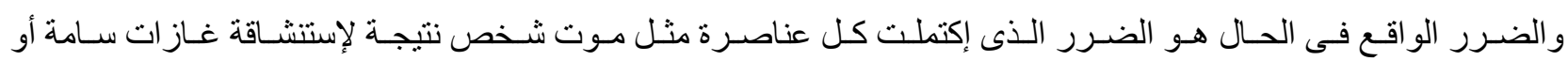

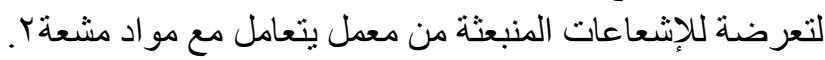
ومتى تحقق فأنه يستوجب التعويض أيا كانت درجة جسامتة وذلك وفقا للقو اعد العامة .

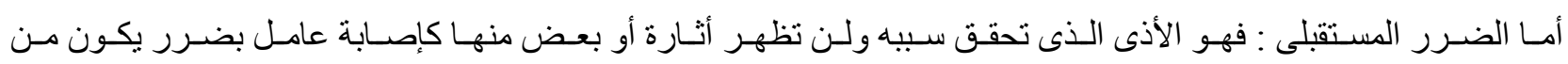

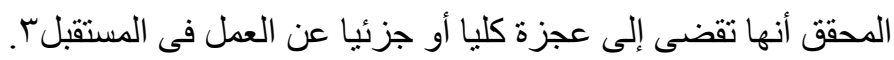

ولكن الملاحظ أن الضرر المستقبلى تعد حالاتة قلبلة مقارنة بعدد حالات الضرر المحقق التى يتم التعويض عنها.

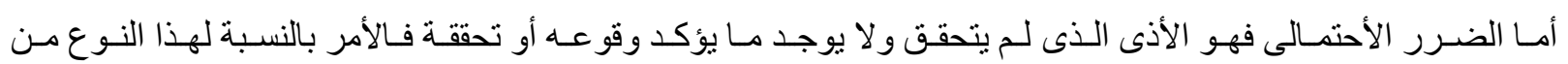

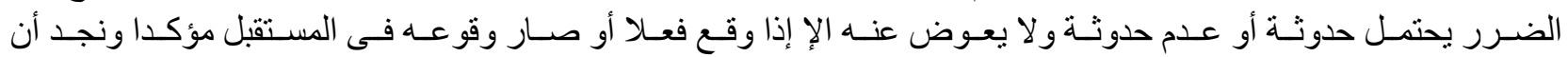

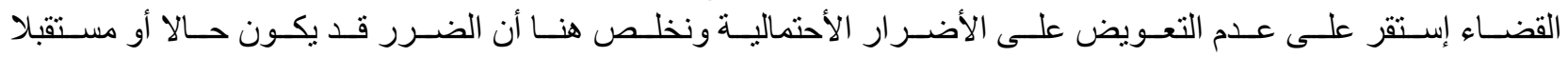

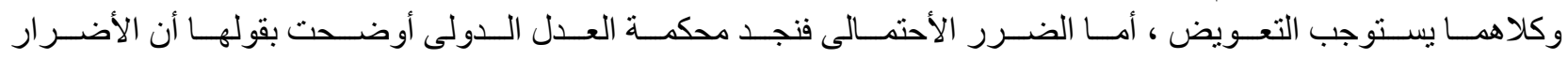

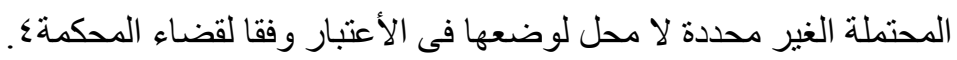

\section{أن يكون الضرر مباشرا:}

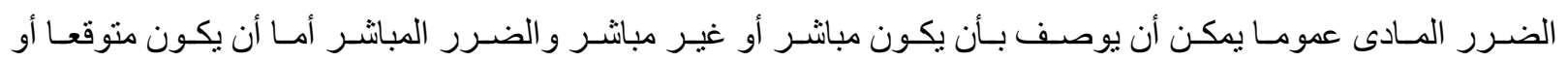

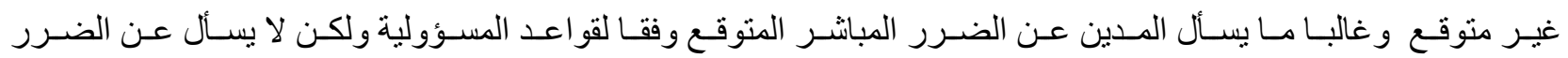

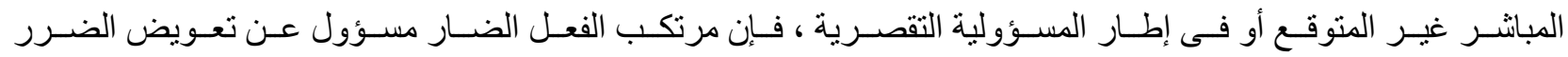

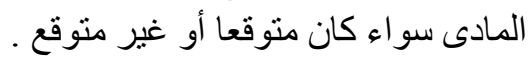

أما الضرر غير المبانشر لا مسؤولية عنه سواء كان متوقع أو غيرمنوقع .

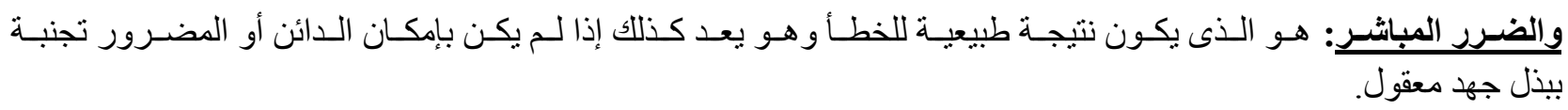

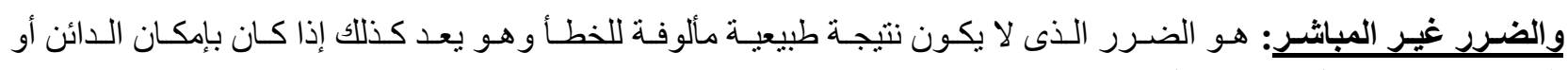

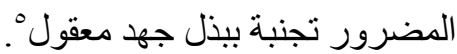

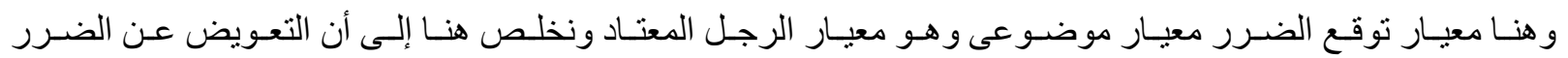

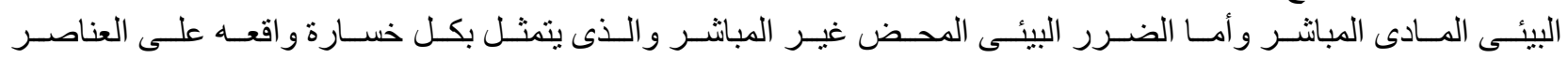

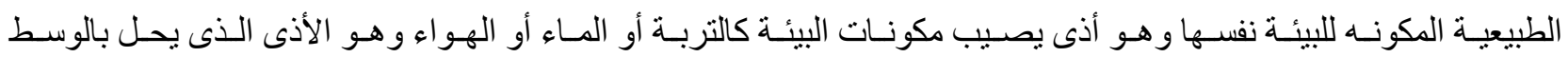

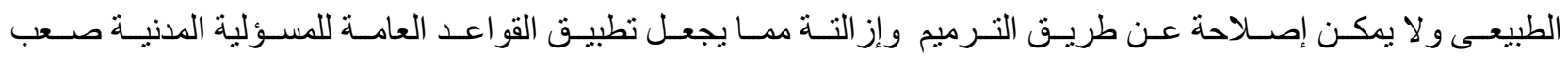

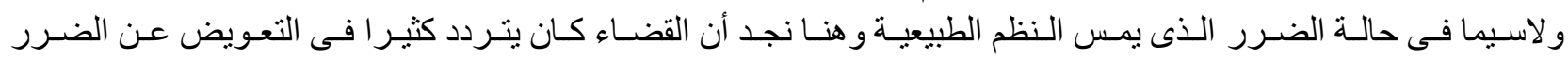

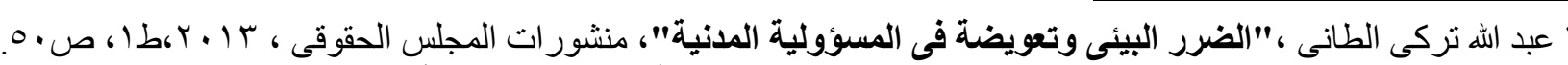

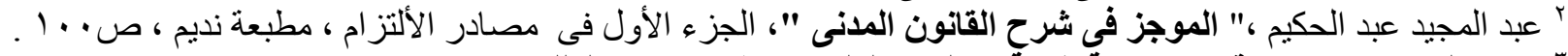

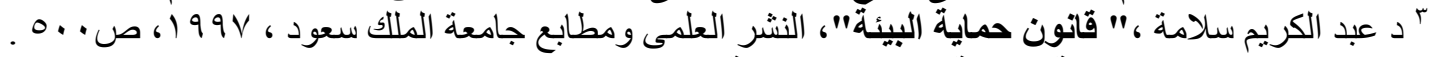

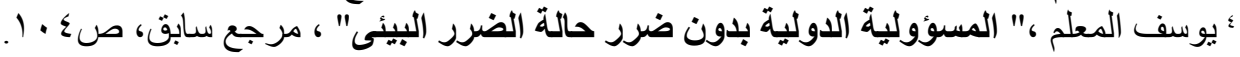

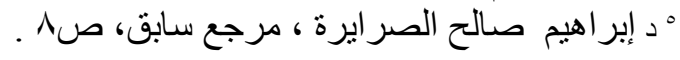




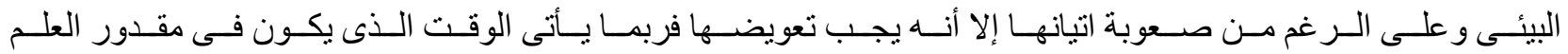

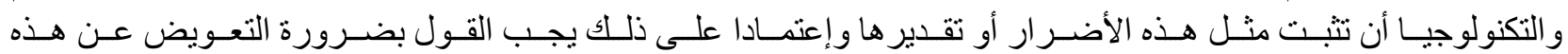
الأضر ار وما ينتج عنها.

\section{أن يكون الضرر البيئى قد أصاب حقا مكتسبا أو مصلحة مشروعة للمضرور:}

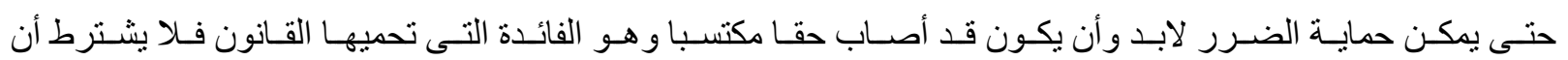

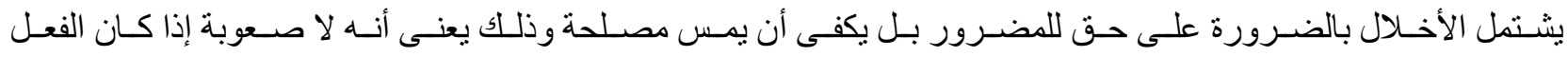

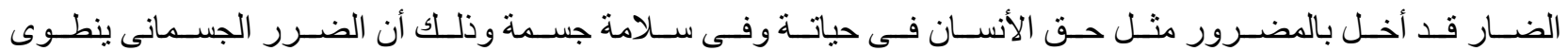

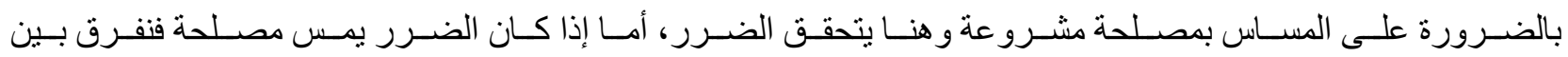

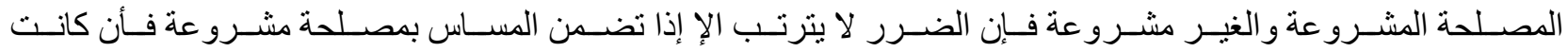

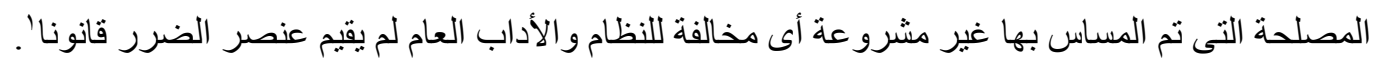

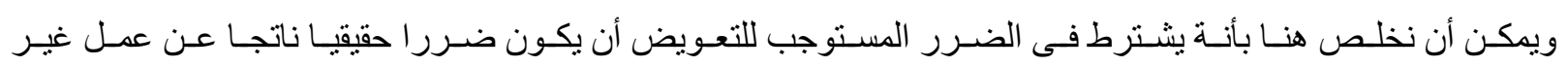

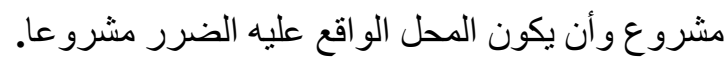

\section{أن يكون الضرر البيئى شخصيا :}

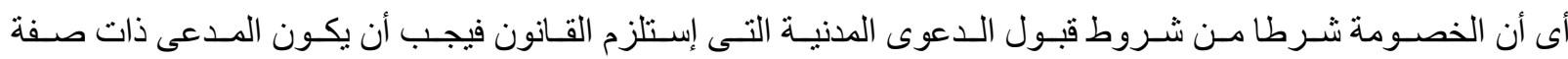

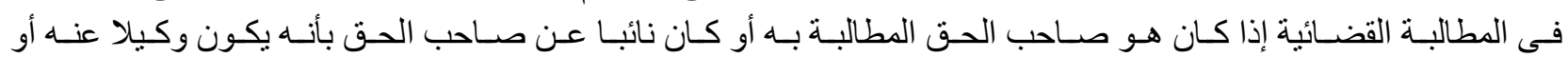

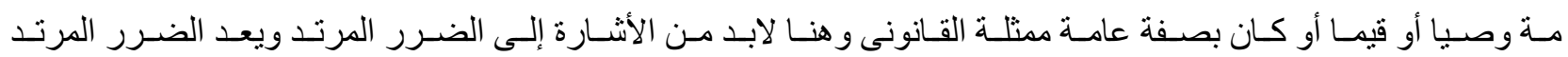

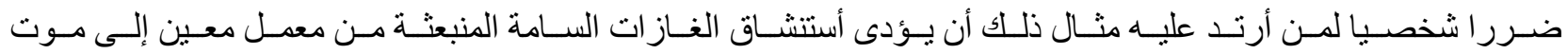

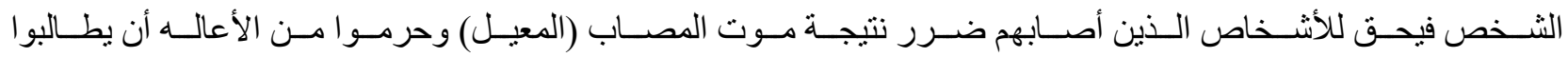

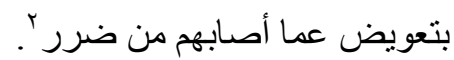

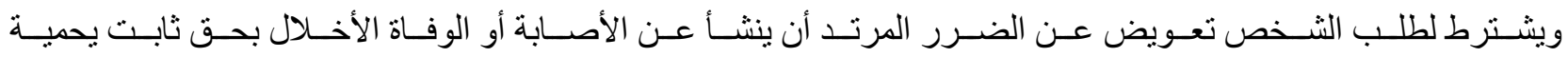
القانون.

\section{الأ يكون الضرر قد سبق تعويضة :}

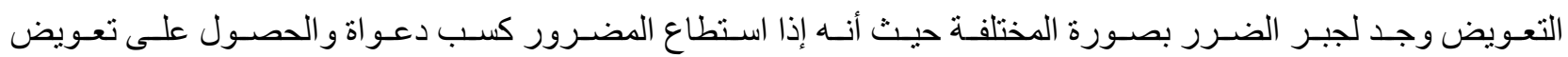

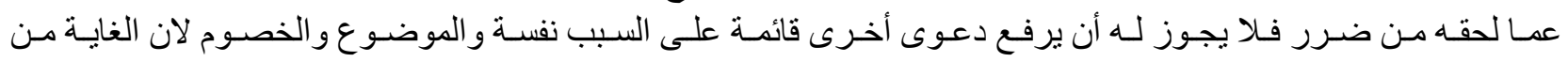

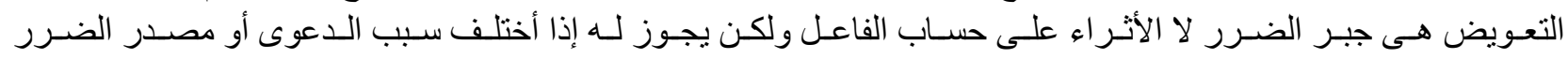

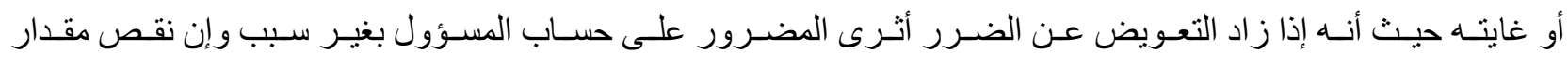

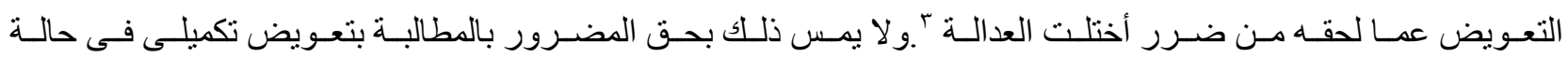

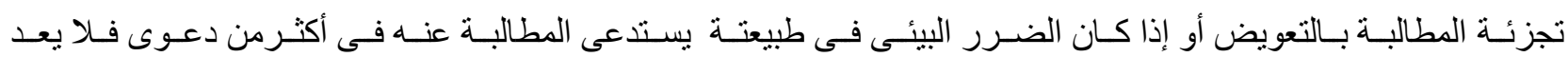

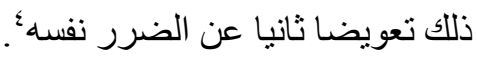

المبحث الرابع

مفهوم التعويض وطرق التعويض

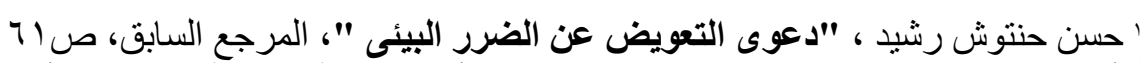

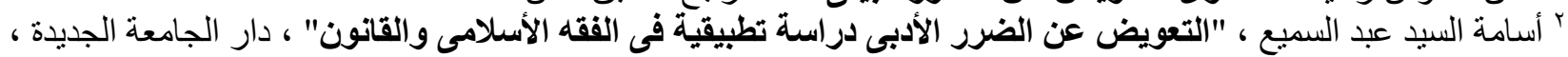

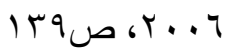

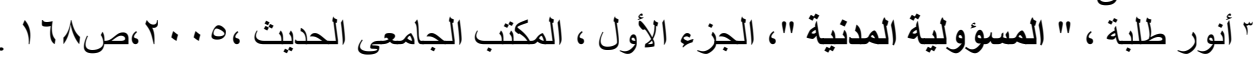

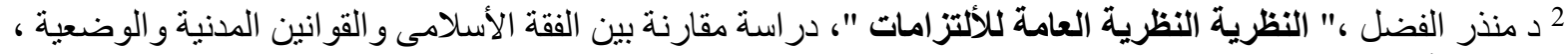

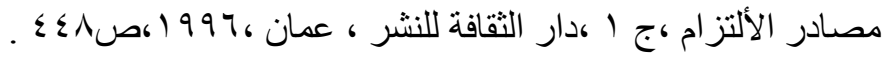




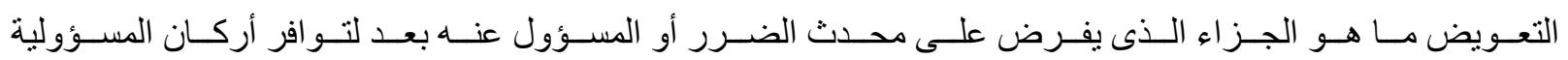

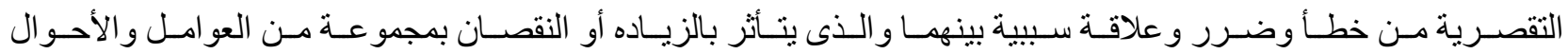
التى تلابس الضرر.

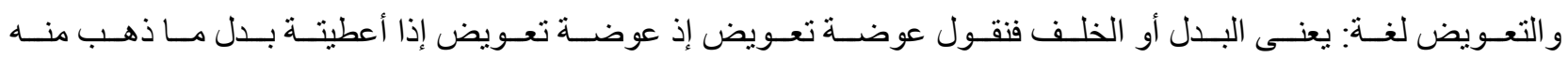

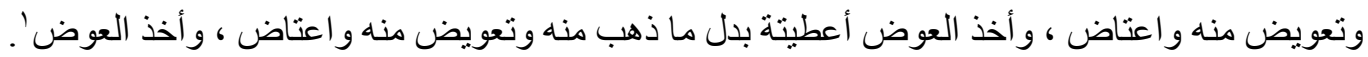

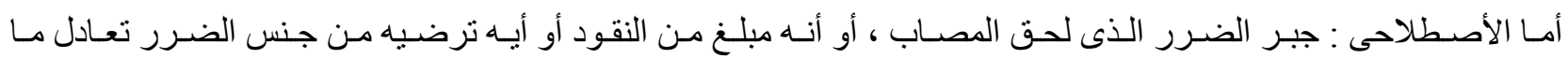

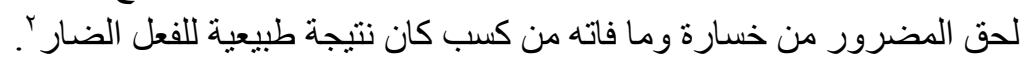
ويعرف التعويض أيضا : يقوم على مبدأ إزالة الضرر البيئى الذى مس الأخرين.

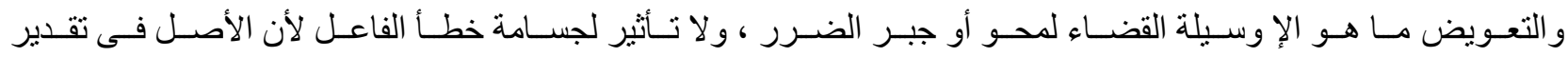

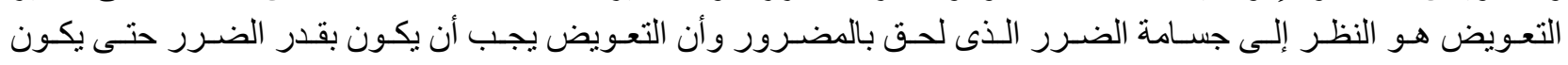

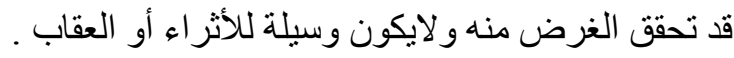

ثانيا: طرق التعويض

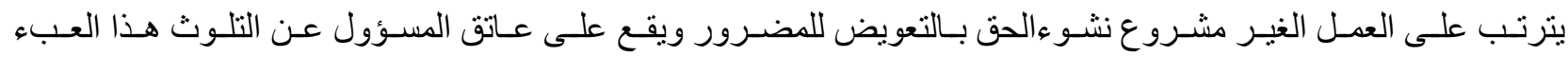

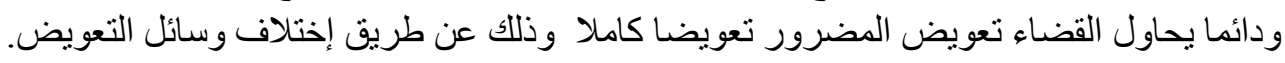

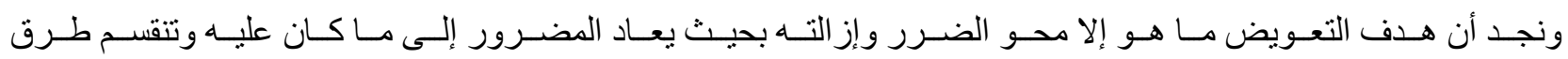
التعويض إلى طريقة التعويض التعويض العينى و النقدى:

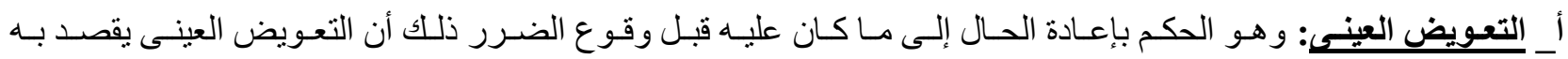

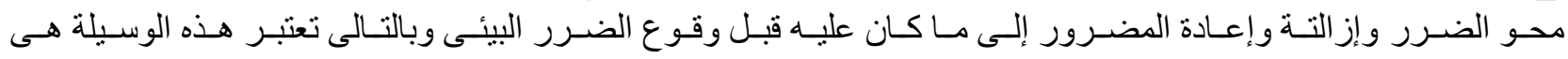

الأفضل منى كان ذلك مدكنا '.

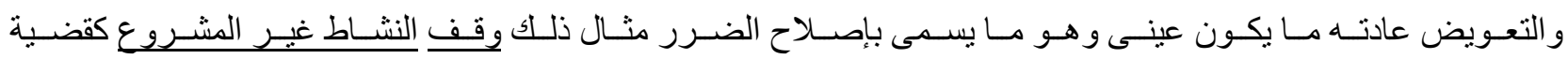

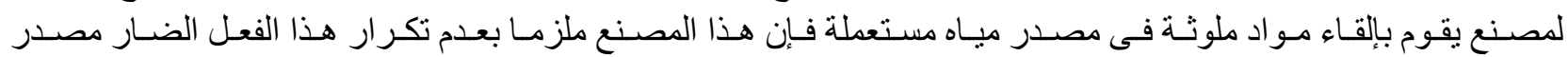

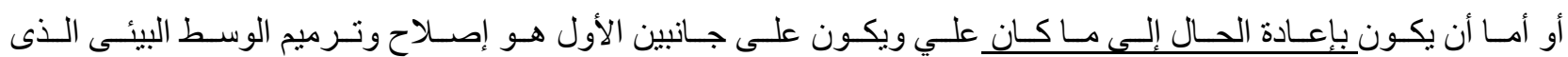

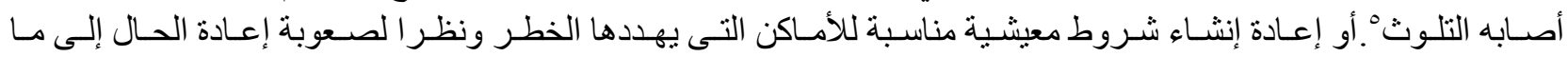

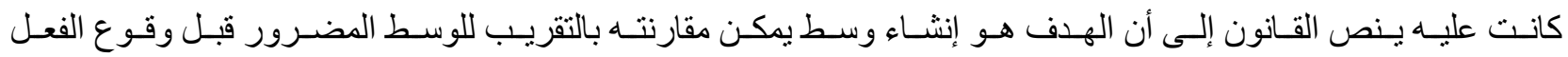

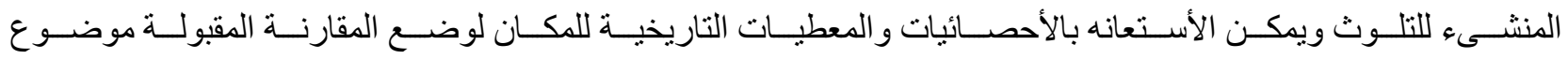

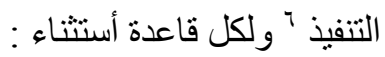

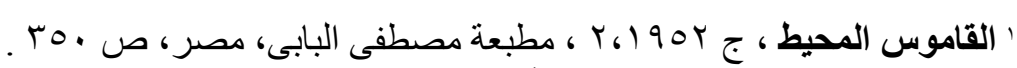

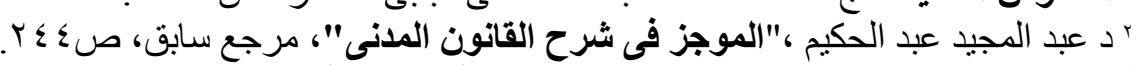

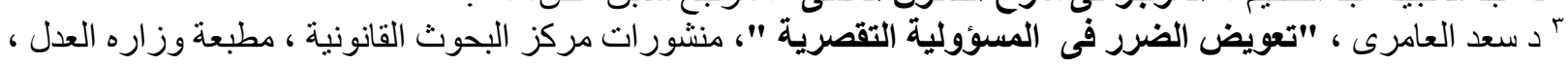

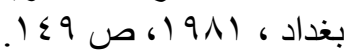
"ُ سعيد السيد قنديل ، "آليات تعويض الأضرار البيئية "، دراسة في ضوء الأنظمة القانونية والأتفاقيات الدولية ، كلية الحقوق ،

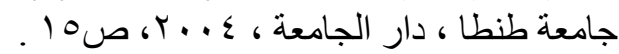

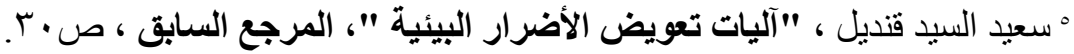

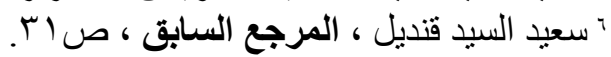




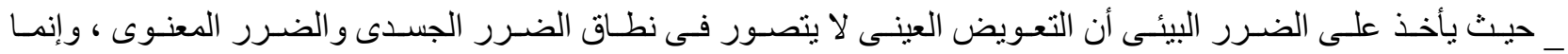

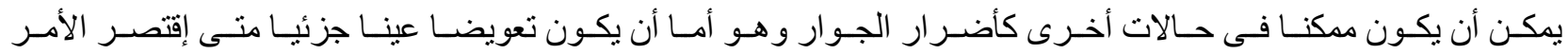

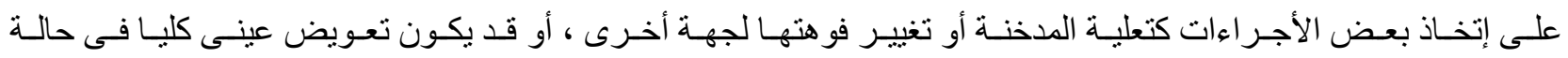

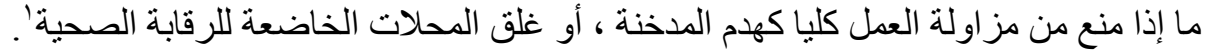

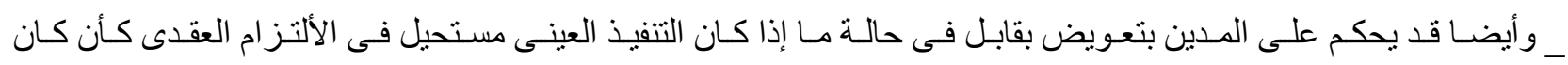
محله عينا معينا بذات و هلكت لسبب أجنبى.

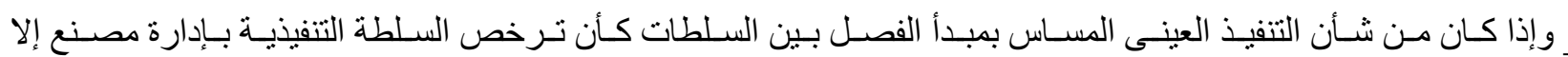

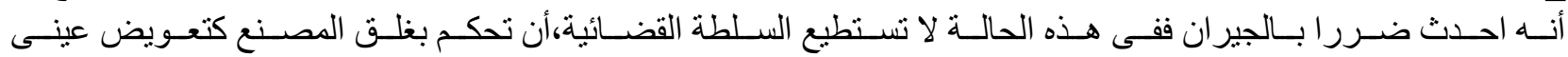

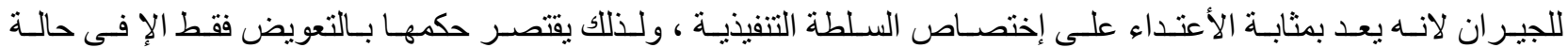

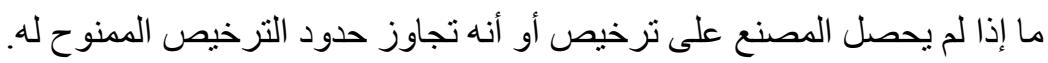

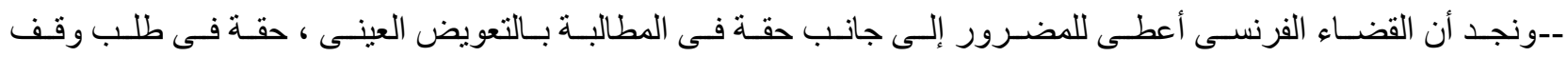

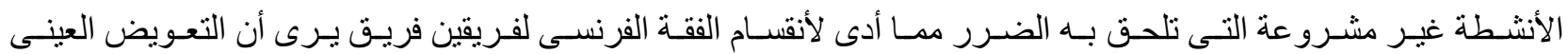

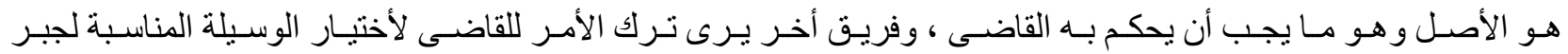

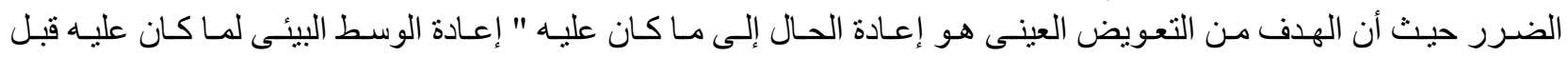

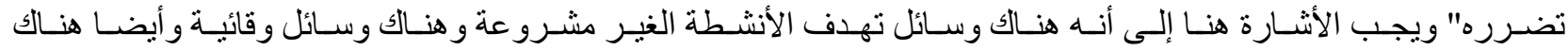

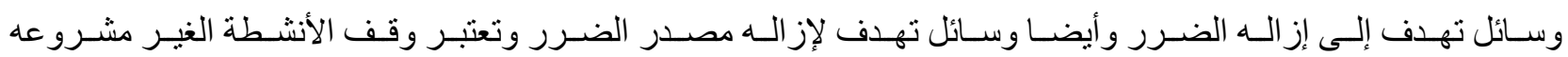

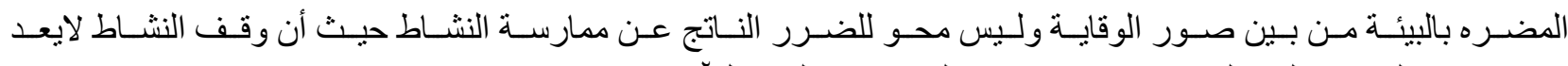

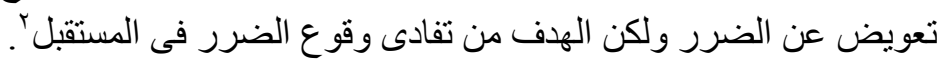

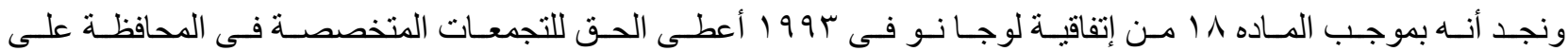

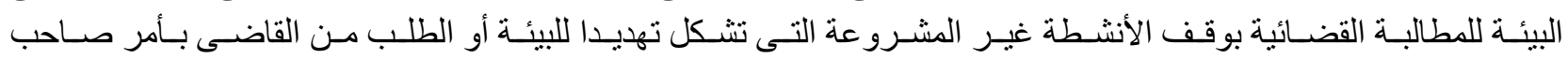

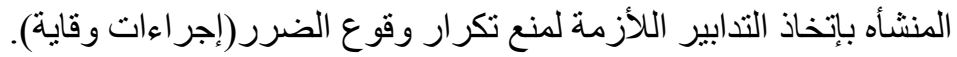

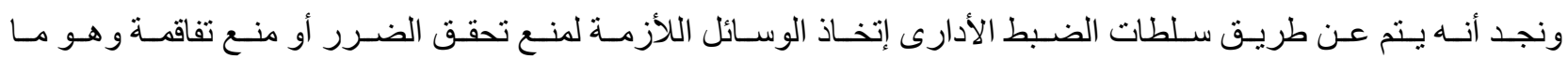
يسمى بوسائل الحماية.

بَ ب التعويض النقدى :

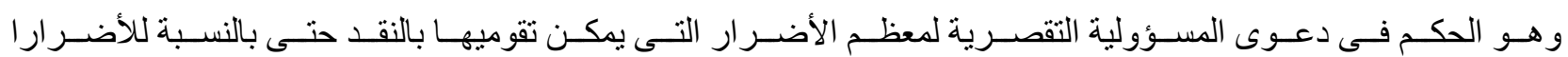

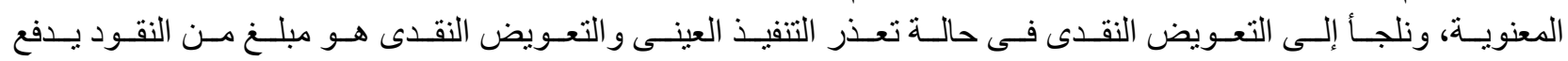
للمتضرر دفعه و احدة وذللك مقابل لما أصابة وعوضا عن التعويض العينى .

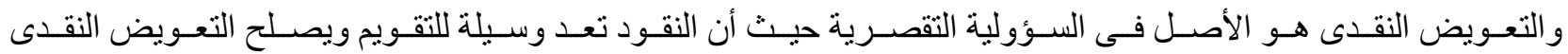
لتعويض المضرور عما أصابة من ضرر بيئى مهما كان نو عهل (جسديا، ماليا ، معنويا) "آ.

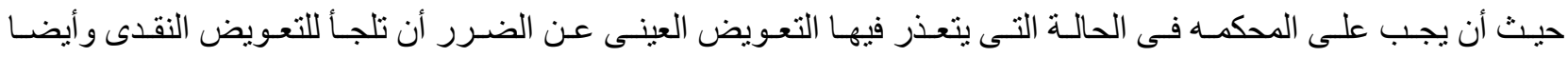

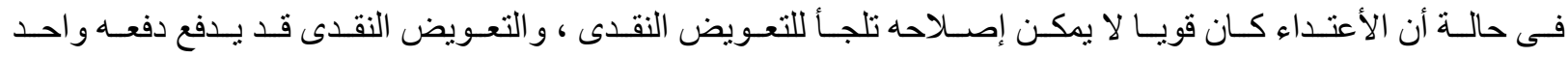

'د يوسف نور الدين، "التعويض عن الضرر البيئى "، مجلة دفاتر السياسة والقانون ، جامعة قاصدى مرباح ورقلة، 9 ، . ؟،

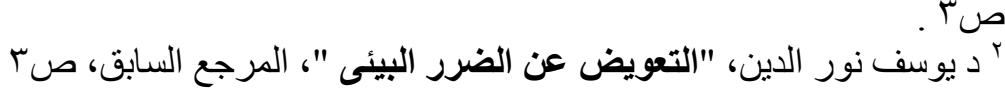

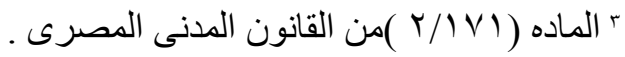


بصـورة إجماليـة للمضـرور وهـذا هـو الأصـل أو يمكن أن يكون على شكل أقسـاط أو يمكن أن يكسون على شـكل مرتـب

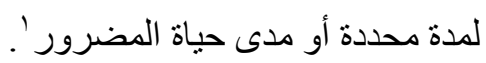

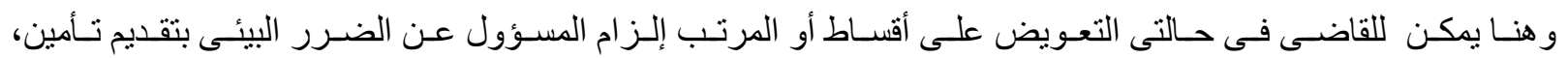

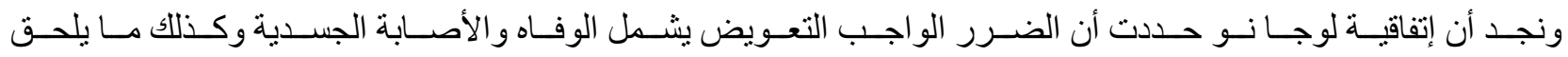

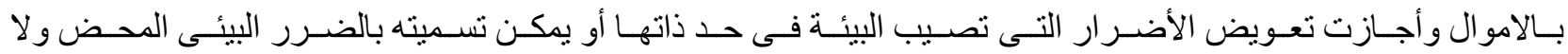

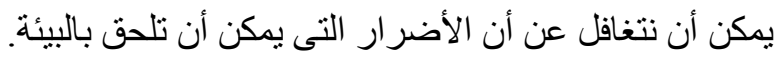

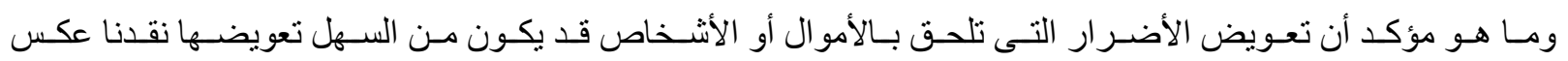

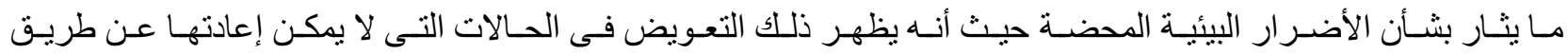

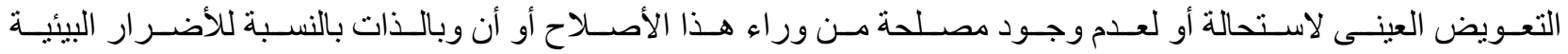

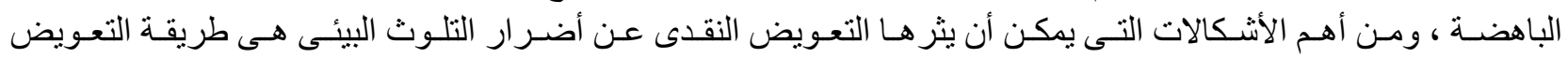
ويمكن الأشارة إليها فيما يلى: الاهن:

\section{أ التقدير الموحد للضرر البيئى:}

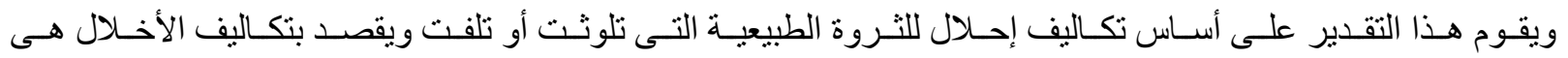

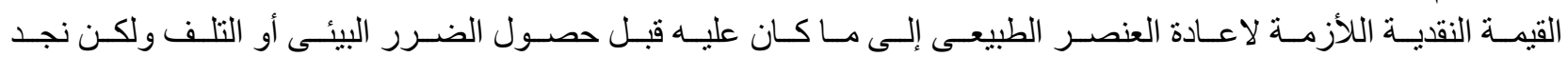

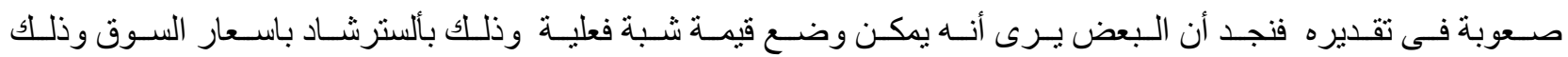

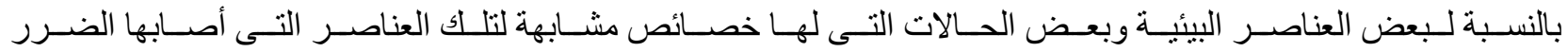

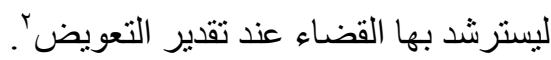

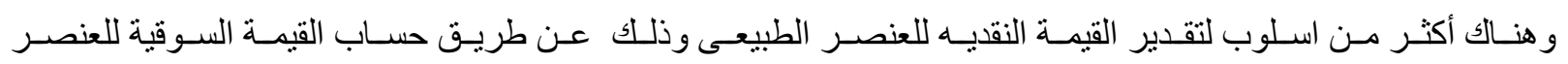

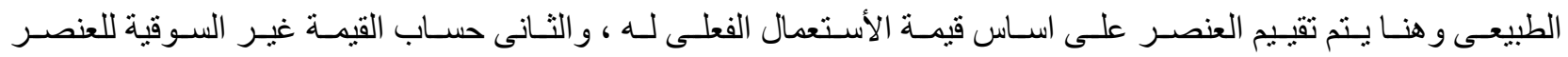

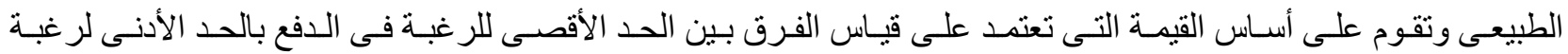

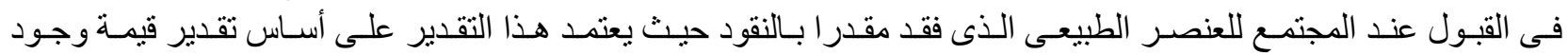

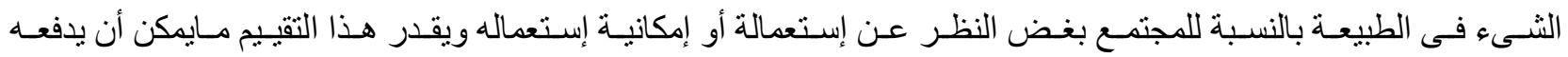
الأشخاص للحصول على الثىء وليس تقيمة على أساس الأستعمال الفعلى أو المستقبلى.

\section{ب التقاير الجزافى للتعويض:}

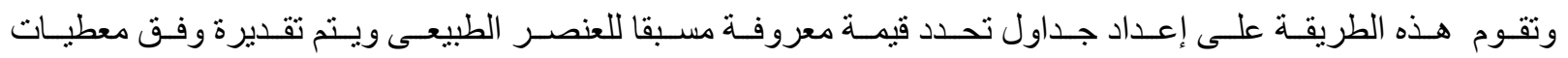

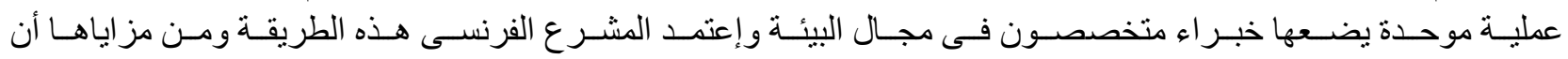

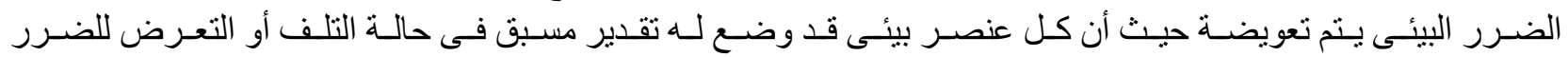

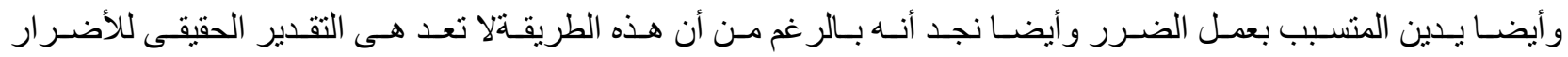
التلوث إلا أنها تحل إنشكالية عدم تعويض النتبئ الأضر ار البيئية.

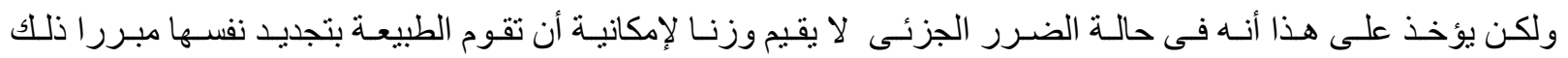

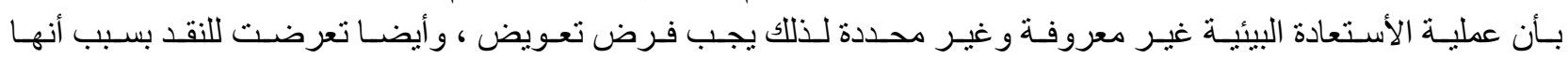

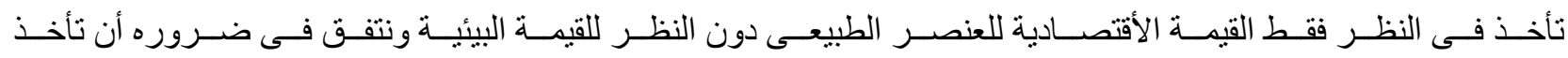

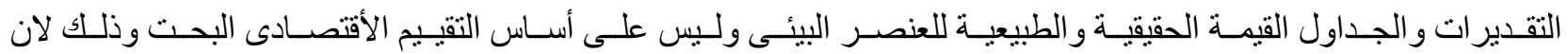

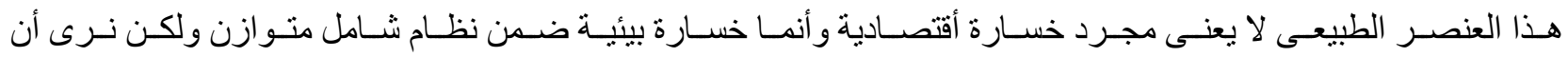

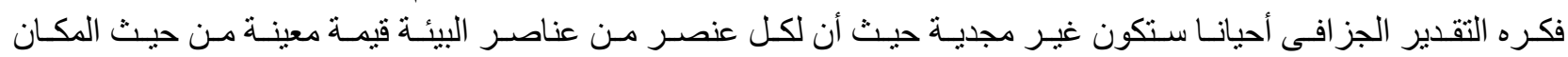

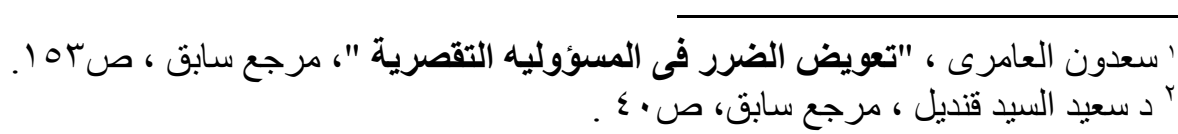




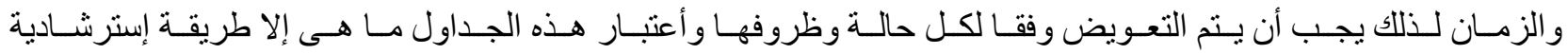

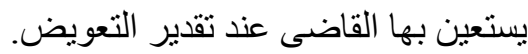

الخلاصة

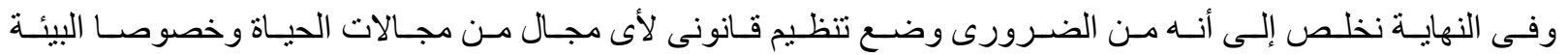

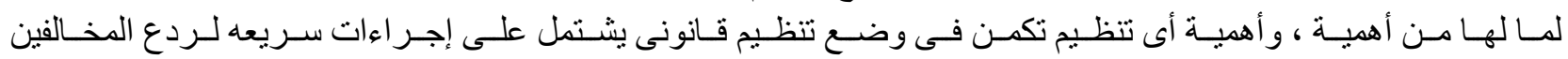

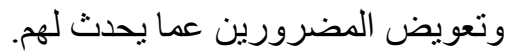

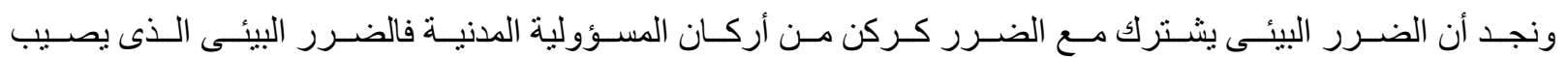

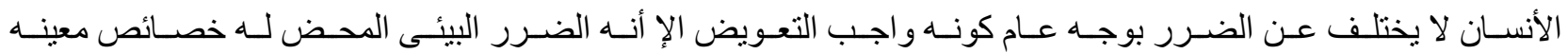

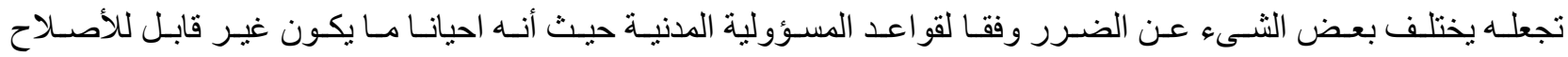

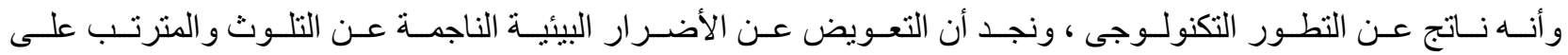

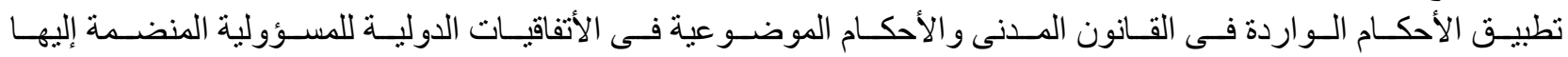
جمهورية مصر العربية أو التى تنظم إليها مستقبلا.

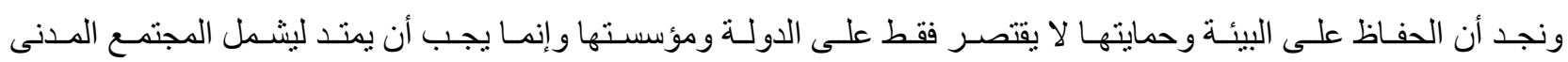

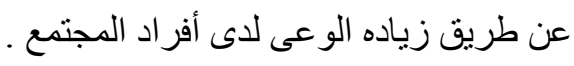

النتائج

أ_ وجدنا أنه ليس هناك مفهوم جامع مانع للضرر البيئى نتيجة للعجلة والتطور العلمى والتكنولوجى.

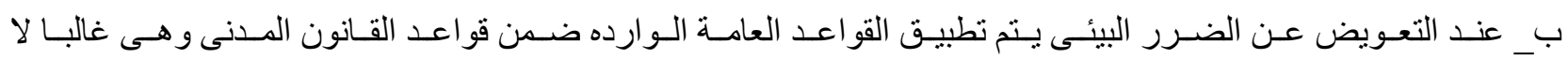

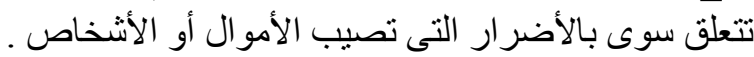

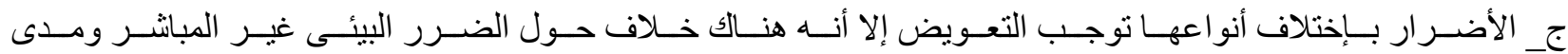

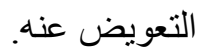

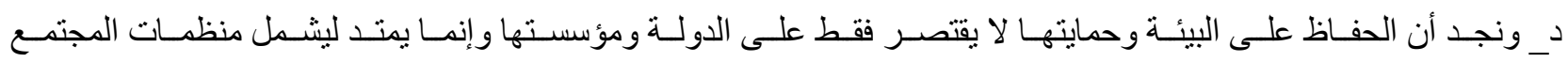
المدنى .

التوصيات

أ_ ضرورة وجود تعريف مانع جامع للضرر البيئى وأيضا مرنا ليشمل كافه مخرجات هذا التطور الذى شهدة العالم.

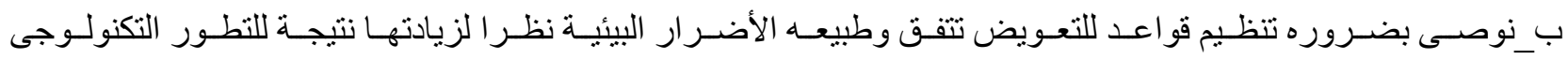

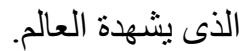

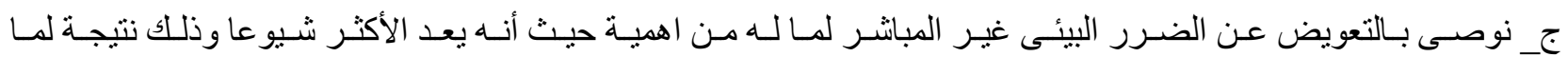

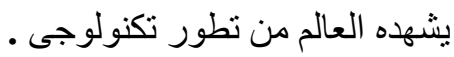

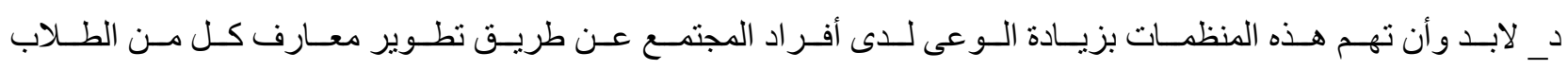

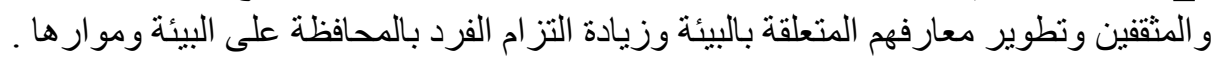

المراجع 


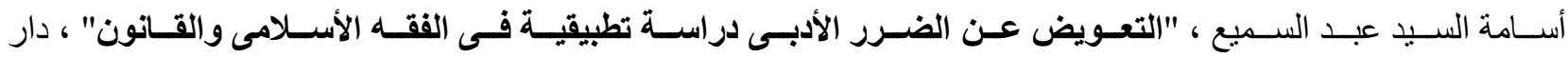

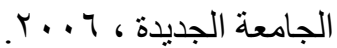

أنور طلبة ، " المسؤولية المدنية "، الجزء الأول ، المكتب الجامعى الحديث ،0.. ب. سليمان مرقس، " شرح القانون المدنى فى الألتزامات"، المطبعة العالمية ،القاهرة.

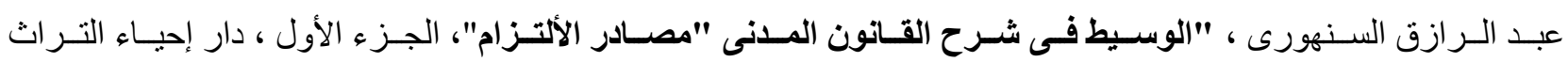

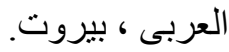

عصام محمد أحمد ،"مفهوم الضرر فى دعوى المسؤولية الدولية "، دار النهضة العربية، القاهرة ، 1990.

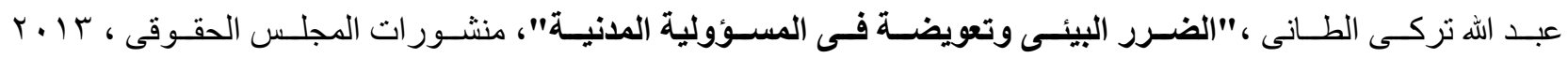
. Ib، عبد المجيد عبد الحكيم ،" الموجز فى شرح القانون المدنى "، الجزء الأول فى مصادر الألنزام ، مطبعة نديم . عبد الكريم سلامة ،" قانون حماية البيئة"، النشر العلمى ومطابع جامعة الملك سعود ، و997 ، . .

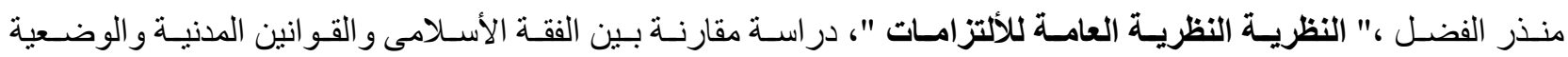

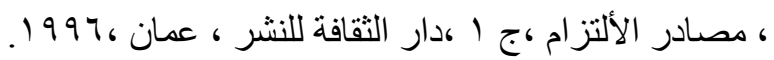

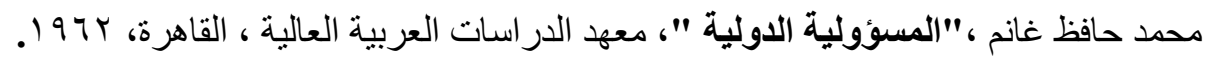
الرسائل العلمية:

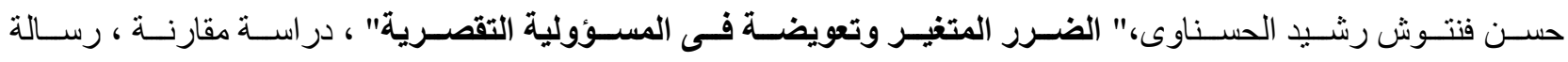

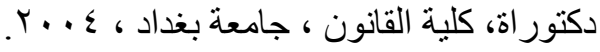

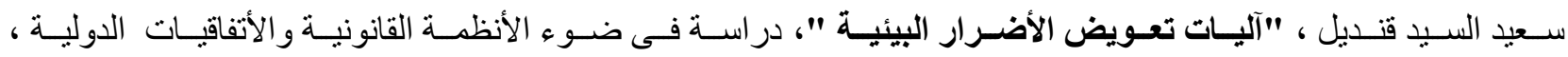

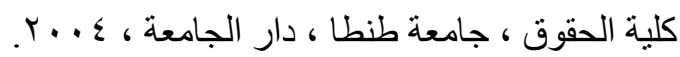

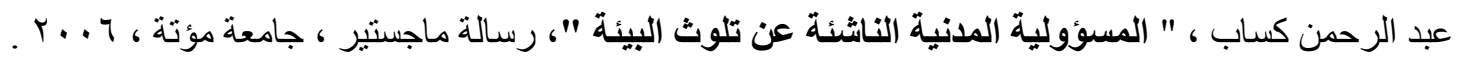

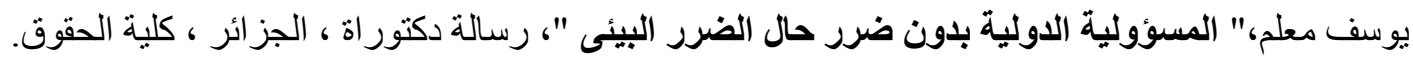
أبحاث ومقالات:

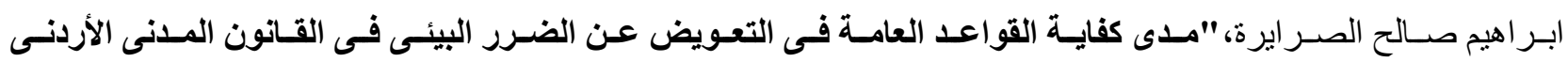

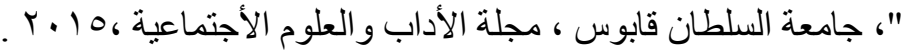

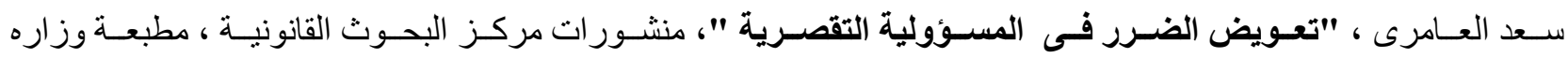

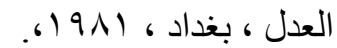

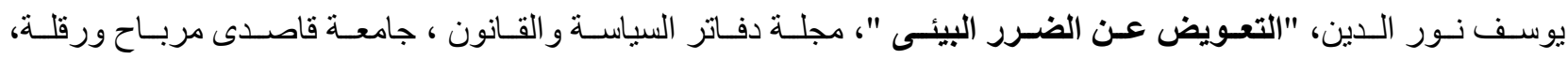
r. . 9 